\title{
EXCRETION OF CALCIUM, PHOSPHORUS, MAGNESIUM AND SODIUM IN LACTATING SOWS
}

\author{
Novotný, J. ${ }^{1}$, Reichel, P. ${ }^{1}$, Kósa, B. ${ }^{2}$, Šipoš, D. ${ }^{2}$ \\ ${ }^{1}$ Clinic for swine, University of Veterinary Medicine and Pharmacy \\ 04181 Košice, Komenského 73 \\ ${ }^{2}$ Private veterinary doctor \\ The Slovak Republic \\ jaroslav.novotny@uvlf.sk
}

\section{ABSTRACT}

The aim of this study was to evaluate the excretion of calcium $(\mathrm{Ca})$, phosphorus $(\mathrm{P})$, magnesium $(\mathrm{Mg})$ and sodium ( $\mathrm{Na}$ ) via milk, urine and faeces during the lactation period of sows. Six clinically healthy lactating sows (crossbreed Large White $\times$ Landrace) were selected for these experiments and were housed in standard conditions and fed with commercially prepared dry mixture for this category of sows. The blood serum, milk, urine and faecal samples were collected on the 7 th, 14 th, $21 \mathrm{st}$, and 28th day of lactation. During four weeks of lactation, we recorded the relatively stable and physiological concentrations of $\mathrm{Ca}, \mathrm{P}, \mathrm{Mg}$ and $\mathrm{Na}$ in blood serum. The analysis of the sow's milk showed the highest concentration of $\mathrm{Ca}$ and $\mathrm{P}$ at the end of lactation, while the highest concentration of $\mathrm{Mg}$ and $\mathrm{Na}$ was observed on the $7 \mathrm{th}$ lactation day. The following macro-mineral excretion was recorded in urine: $98.83-194.00 \mathrm{mg}^{-1^{-1}}$ for Ca; $11.88-$ 53.09 mg. $\mathrm{l}^{-1}$ for $\mathrm{P}$; $171.67-344.05 \mathrm{mg} . \mathrm{l}^{-1}$ for $\mathrm{Mg}$; and $56.50-74.83 \mathrm{mg} . \mathrm{l}^{-1}$ for $\mathrm{Na}$; and in the faeces, 1824.5 $3045.5 \mathrm{mg} . \mathrm{kg}^{-1}$ for $\mathrm{Ca}$; $1566.93-2483.2 \mathrm{mg} . \mathrm{kg}^{-1}$ for $\mathrm{P}$;
1916.2-2505.2 mg. $\mathrm{kg}^{-1}$ for $\mathrm{Mg}$; and $516.8-748.2 \mathrm{mg}$. $\mathrm{kg}^{-1}$ for $\mathrm{Na}$.

Key words: blood serum; faeces; lactating sows; macro-minerals; milk; urine

\section{INTRODUCTION}

Minerals are important constituents of any animal's diet. Swine require 15 minerals in their diet and macrominerals are the minerals that swine need in larger quantities, usually designated as a percent of the diet or in grams. The macro-minerals include calcium, phosphorus, sodium, chlorine, potassium, magnesium, and sulphur. They have many diverse physiological roles within the body, from regulatory to structural functions. The mineral requirements of pigs are influenced by; the type and level of production, the age and breed of the animal, the interrelationship and associations between minerals and other nutrients, as well as the quantity and chemical form of the mineral element themselves [5]. 
Absorbed minerals are incorporated into body tissue, stored in reserve for later use, or excreted. Pigs through the faeces and urine, normally excrete around 45 to $60 \%$ of nitrogen, 50 to $80 \%$ of calcium and phosphorous, and 70 to $90 \%$ of potassium, sodium, magnesium, copper, zinc, manganese and iron, when fed diets containing commonly used feedstuffs [18]. The level of some minerals, such as nitrogen and phosphorous in pig faeces is very important because of the risk of soil and water contamination [26].

The critical stage in the mineral nutrition of a sow is during late gestation and lactation [23]. The single most important demand on the lactating sow for minerals is for the production and secretion of milk to nourish the rapidly growing neonate [27]. Mammary mineral transfer to milk remain fairly regular even under varying maternal mineral status levels. This sensitive control is necessary in order to prevent toxicities or deficiencies in the offspring. In addition, to meet the neonatal demands, the dam will use up her body mineral reserves and catabolise skeletal tissue before the progeny becomes malnourished [17]. This depletion has been demonstrated in the skeletal demineralization of sows with increasing parity [14], [24]. Thus, lactation can severely deplete the sow's body stores of nutrients.

The aim of this study was to evaluate the concentrations of $\mathrm{Ca}, \mathrm{P}, \mathrm{Mg}$ and $\mathrm{Na}$ in the blood serum, milk, urine and faeces of lactating sows during four weeks after parturition.

\section{MATERIALS AND METHODS}

Six lactating sows (crossbreed Large White $\times$ Landrace) in the age of 2.5-5.0 years (average litter size 12), and average body weight $220 \mathrm{~kg}$, were used in our experiments. During four weeks, the sows were fed with a concentrated feed mixture (OŠ-09) for lactating pigs (Tajba a.s., SR). The diet was based on corn, soybean extracted ground meal, barley and wheat. In addition, OŠ-09 contained per $1 \mathrm{~kg}$ of DM: vitamin A, $6000 \mathrm{U}$; vitamin D3, $600 \mathrm{U}$; NC, $155 \mathrm{~g}$; $\mathrm{DF}, 70 \mathrm{~g}$; lysine, $7.5 \mathrm{~g}$; threonine, $4.5 \mathrm{~g}$; methionine and cysteine, $4.0 \mathrm{~g}$; Ca, $7.0 \mathrm{~g}$; P, $5.0 \mathrm{~g} ; \mathrm{Na}, 2.0 \mathrm{~g} ; \mathrm{Mg}$, 0,5 g; vitamin E, $20 \mathrm{mg}$; Fe, $240 \mathrm{mg} ; \mathrm{Zn}, 110 \mathrm{mg}$; and Cu, $20 \mathrm{mg}$. The diet covered the standardized nutritional requirements of lactating pigs [28]. We used a divided type of feeding (three times daily) corresponding to the count of new-born piglets $(6.80 \mathrm{~kg}$ of concentrated feed mixture per lactating sow with 12 piglets per day). The sows were housed individu- ally in the standard farrowing pens with free access to water. The blood, urine and faeces were sampled in one-week intervals: $1 \mathrm{st}, 2 \mathrm{nd}, 3 \mathrm{rd}$, 4 th sampling on 7 th, 14th, 21st, and 28th day after farrowing, respectively. The blood was taken from the vena cava cranialis. Samples of milk were collected during the morning sucking of the piglets. The specimens were stored at $-24^{\circ} \mathrm{C}$ until analysis. All samples were subjected to wet mineralization in a microwave oven. The concentrations of $\mathrm{Ca}, \mathrm{Mg}$, and $\mathrm{Na}$ in the blood serum, milk, faeces, and urine were determined by the flame AAS method (Perkin Elmer, AAnalyst 100) [4]. The concentration of $\mathrm{P}$ in the faeces and milk was determined using a spectrophotometer SPECOL 211 (Carl Zeiss Jena), the concentrations of $\mathrm{P}$ in the blood plasma and urine were determined by an automatic biochemical analyser ALIZE (Lisabio) using diagnostic kits (Bio Mérieux, Randox) [12].

The statistical analysis was done using one-way analysis of variance (ANOVA) with the post hoc Tukey multiple comparison tests. Results in tables are presented as means ( $\mathrm{x}$ ) and the standard deviation (SD).

\section{RESULTS AND DISCUSSION}

Calcium (Ca) and phosphorus (P) are minerals that have important physiological functions in the body such as; muscle contraction, transmission of nerve impulses, enzyme activation, metabolic reactions, protein synthesis, maintenance of osmotic and acid-base balances, components in membranes, and other functions [6], [11]. An important aspect of $\mathrm{Ca}$ and $\mathrm{P}$ metabolism is plasma homeostasis, which is controlled by absorption, urinary excretion, and bone turnover [3], [13]. A major part of the $\mathrm{Ca}$ in swine diets originates from inorganic sources because the concentration of $\mathrm{Ca}$ in cereal grains is low. Most of the phosphorus in cereal grains and oilseed meal is in the form of phytic acid (organically bound phosphorus) and is poorly available to pigs. Supplemental phytase, an enzyme that degrades some of the phytic acid in feedstuffs, is commonly added to diets to further reduce phosphorus excretion [8]. However, it's necessary to remember that, high levels of $\mathrm{Ca}$ in swine diets reduce the effect of phytase and affect the digestibility of $\mathrm{P}$ [19].

Magnesium (Mg) has several important functions, as for example; a cofactor for protein and DNA synthesis, oxidative phosphorylation, cardiovascular tone, and neuro- 
Table 1. The concentration of macro-elements in blood serum of lactating sows in $\mathrm{mmol}^{-\mathrm{I}^{-1}}(\mathrm{x} \pm \mathrm{SD})$

\begin{tabular}{ccccc}
\hline \multirow{2}{*}{ Sampling } & $\mathrm{Ca}$ & $\mathbf{P}$ & $\mathrm{Mg}$ & $\mathrm{Na}$ \\
\hline \multirow{2}{*}{1 st } & $2.45 \pm$ & $1.91 \pm$ & $0.95 \pm$ & $140 \pm$ \\
& 0.16 & 0.57 & 0.22 & 5.67 \\
\multirow{2}{*}{ 2nd } & $2.32 \pm$ & $2.23 \pm$ & $1.00 \pm$ & $143 \pm$ \\
& 0.20 & 1.07 & 0.22 & 4.78 \\
\multirow{2}{*}{ 3rd } & $2.44 \pm$ & $2.80 \pm$ & $0.91 \pm$ & $145 \pm$ \\
& 0.27 & 0.96 & 0.09 & 6.99 \\
\multirow{2}{*}{ 4th } & $2.33 \pm$ & $2.40 \pm$ & $0.91 \pm$ & $145 \pm$ \\
& 0.18 & 0.64 & 0.13 & 4.62 \\
\hline
\end{tabular}

Table 2. The concentration of macro-elements in the milk of lactating sows in $\mathrm{mg} \mathrm{I}^{-1}(\mathrm{x} \pm \mathrm{SD})$

\begin{tabular}{|c|c|c|c|c|}
\hline Sampling & $\mathrm{Ca}$ & $\mathbf{P}$ & $\mathrm{Mg}$ & $\mathrm{Na}$ \\
\hline $1 s t$ & $\begin{array}{c}1287.83 \pm \\
364.95\end{array}$ & $\begin{array}{c}6.98 \pm \\
4.21\end{array}$ & $\begin{array}{c}115.83 \pm \\
72.45\end{array}$ & $\begin{array}{c}695.67 \pm \\
382.92\end{array}$ \\
\hline 2nd & $\begin{array}{c}1713.33 \pm \\
273.69\end{array}$ & $\begin{array}{c}9.21 \pm \\
3.00\end{array}$ & $\begin{array}{c}107.00 \pm \\
41.29\end{array}$ & $\begin{array}{c}445.83 \pm \\
195.97\end{array}$ \\
\hline $3 r d$ & $\begin{array}{c}1817.17 \pm \\
244.41\end{array}$ & $\begin{array}{c}8.96 \pm \\
3.32\end{array}$ & $\begin{array}{c}106.83 \pm \\
45.56\end{array}$ & $\begin{array}{c}350.33 \pm \\
53.39\end{array}$ \\
\hline 4th & $\begin{array}{c}1783.83 \pm \\
320.40\end{array}$ & $\begin{array}{c}11.4 \pm \\
0.26\end{array}$ & $\begin{array}{c}103.33 \pm \\
6.88\end{array}$ & $\begin{array}{c}381.67 \pm \\
101.00\end{array}$ \\
\hline
\end{tabular}

muscular excitability [3]. It is associated with calcium and phosphorus in bone, the largest reservoir of these minerals, from which it can be released to the body as required. Magnesium is readily available in plant sources, and is absorbed from the small intestine. It is thought to be efficiently recycled so that supplementation is not necessary to fulfil most requirements [5]. On the other hand, studies have demonstrated that supplementing $\mathrm{Mg}$ to swine diets; alleviated the effects of stress and improved the meat quality [2], [10], and prevented and controlled the occurrence of constipation [29]. Magnesium is stored in bone or excreted in the urine [13], [30].

Sodium $(\mathrm{Na})$ is necessary for; the generation of nerve impulses, for maintenance of electrolyte balance and fluid balance, heart activity and certain metabolic functions [25]. Sodium together with chloride are available from feed grains, but only in low concentration, therefore they are provided as supplements to diets, especially during lactation to maintain the physiological balance of these minerals
Table 3. The concentration of macro-elements in the urine of lactating sows in $\mathrm{mg}^{-\mathrm{I}^{-1}}(\mathrm{x} \pm \mathrm{SD})$

\begin{tabular}{ccccc}
\hline Sampling & Ca & $\mathbf{P}$ & Mg & $\mathrm{Na}$ \\
\hline \multirow{2}{*}{ 1st } & $98.83 \pm$ & $22.05 \pm$ & $171.67 \pm$ & $56.50 \pm$ \\
& 92.34 & 33.16 & 164.51 & 51.14 \\
\multirow{2}{*}{ 2nd } & $116.17 \pm$ & $11.88 \pm$ & $344.5 \pm$ & $74.83 \pm$ \\
& 85.39 & 9.26 & 331.69 & 57.80 \\
\multirow{2}{*}{ 3rd } & $116.00 \pm$ & $19.36 \pm$ & $282.33 \pm$ & $58.67 \pm$ \\
& 75.00 & 15.51 & 155.10 & 32.75 \\
\multirow{2}{*}{ 4th } & $194.00 \pm$ & $53.09 \pm$ & $285.50 \pm$ & $63.33 \pm$ \\
& 195.06 & 85.22 & 233.34 & 43.89 \\
\hline
\end{tabular}

Table 4. The concentration of macro-elements in the faeces of lactating sows in $\mathrm{mg}^{\mathrm{kg}} \mathrm{kg}^{-1}(\mathrm{x} \pm \mathrm{SD})$

\begin{tabular}{|c|c|c|c|c|}
\hline Sampling & $\mathrm{Ca}$ & $\mathbf{P}$ & $\mathrm{Mg}$ & $\mathrm{Na}$ \\
\hline $1 s t$ & $\begin{array}{c}3045.5 \pm \\
1604.4\end{array}$ & $\begin{array}{c}1857.9 \pm \\
870.6\end{array}$ & $\begin{array}{c}2505.2 \pm \\
566.2\end{array}$ & $\begin{array}{c}517.5 \pm \\
426.8\end{array}$ \\
\hline 2nd & $\begin{array}{c}2282.1 \pm \\
1585.6\end{array}$ & $\begin{array}{c}2483.2 \pm \\
1388.3\end{array}$ & $\begin{array}{c}2170.9 \pm \\
387.3\end{array}$ & $\begin{array}{c}516.8 \pm \\
447.3\end{array}$ \\
\hline $3 r d$ & $\begin{array}{c}1824.5 \pm \\
845.3\end{array}$ & $\begin{array}{c}1566.93 \pm \\
809.3\end{array}$ & $\begin{array}{c}1919.9 \pm \\
357.4\end{array}$ & $\begin{array}{c}648.9 \pm \\
510.65\end{array}$ \\
\hline 4th & $\begin{array}{c}1858.2 \pm \\
1610.2\end{array}$ & $\begin{array}{c}1656.9 \pm \\
815.3\end{array}$ & $\begin{array}{c}1916.2 \pm \\
410.5\end{array}$ & $\begin{array}{c}748.2 \pm \\
610.5\end{array}$ \\
\hline
\end{tabular}

[22]. These minerals are provided by common salt, which contains $40 \%$ of sodium and $60 \%$ of chloride. The recommended level of salt is $0.5 \%$ in sow diets [8].

The concentration of $\mathrm{Ca}, \mathrm{P}, \mathrm{Mg}$ and $\mathrm{Na}$ revealed no significant differences in the blood serum of lactating sows within the four samplings (Table 1). The concentrations of all these elements was physiological when compared with the physiological range of $\mathrm{Ca}, \mathrm{P}, \mathrm{Mg}$ and $\mathrm{Na}$ which is $2.0-$ $3.0 \mathrm{mmol.} \mathrm{l}^{-1}, 1.30-3.55 \mathrm{mmol.} \mathrm{l}^{-1} 1,0.7-1.6 \mathrm{mmol}^{-\mathrm{l}^{-1}}$, and 135-145 mmol. $\mathrm{l}^{-1}$ [31] for pigs, respectively. But our values were lower than those obtained by Žvorc et al. [32].

The peak daily milk yield is reached at around 21 days of lactation [9], and general milk composition after day 7 is relatively stable for the remainder of lactation. The major components of milk solids (17 to $25 \%$ ) are; fat (7 or $8 \%$ ), lactose $(\sim 4 \%)$, and protein $(6 \%)$. The other major components of milk are the ash or mineral contents. Sow's milk contains 0.6 to $1.0 \%$ ash, with the majority of that as calcium and phosphorus [16]. The calcium and phosphorus 
composition of milk seems stable despite fluctuations in dietary intake [5]. The body reserves are sufficient to buffer this need, and are utilised especially in sows with high milk production. If the reserves of calcium and phosphorus are not replenished, then the strength and integrity of the sow's bones will decrease [5]. Our results are in accordance with the finding of Mahan and Fetter [21], that sow's milk has a higher concentration of $\mathrm{Ca}$ and $\mathrm{P}$ in the third and fourth weeks of lactation than the first two weeks. The lowest concentration of $\mathrm{Ca}$ was found in the 1st week (1287 mg. $1^{-1}$; Table 2), and the highest in the $3 \mathrm{rd}$ week $\left(1817 \mathrm{mg} \cdot \mathrm{l}^{-1}\right)$. Similarly, the lowest concentration of $\mathrm{P}$ was observed in the 1 st week (6.98 mg. $\left.{ }^{-1}\right)$, and the highest in the 4 th week $\left(11.4 \mathrm{mg} \cdot \mathrm{l}^{-1}\right)$. The milk concentrations of $\mathrm{Mg}$ and $\mathrm{Na}$ ranged between 103.33-115.83 and 350.33$695.67 \mathrm{mg} . \mathrm{l}^{-1}$, respectively.

The kidneys play a central role in the homeostasis of calcium, phosphorus, and magnesium. Gastrointestinal absorption is balanced by renal excretion. When the body stores of these ions decline significantly, gastrointestinal absorption, bone resorption, and renal tubular reabsorption increase to normalize their levels. Renal regulation of these ions occurs through glomerular filtration and tubular reabsorption and/ or secretion [3]. Sodium is also excreted primarily in the urine, with only small amounts lost in the faeces and perspiration [20]. The highest nonsignificant urinary excretion was recorded on 28th day of lactation for $\mathrm{Ca}, \mathrm{P}$ (4th sampling), and on the 14th day of lactation for $\mathrm{Mg}, \mathrm{Na}$ (Table 3).

The concentration of the macro-minerals in the faeces of lactating sows was without significant differences between the four collections (Table 4). The faecal output of minerals included both unabsorbed dietary minerals and minerals that had been secreted into the intestine and not reabsorbed (usually referred to as endogenous faecal excretion) [1]. The daily faecal production in relation to the body weight (DFP/BW) is around $0.6 \%$ [7] and the dry matter content of faeces (DMF) varies around $30 \%$ [15]. As mentioned above, phosphorus is considered a potential environmental pollutant. Excretion of $\mathrm{P}$ in the urine of lactating sows changed from 11.88 to $53.09 \mathrm{mg}^{-1} \mathrm{l}^{-1}$ (Table 3 ). Faecal output of phosphorus varied between 1566.93 and $2483.2 \mathrm{mg} \cdot \mathrm{kg}^{-1}$ (Table 4 ), but these values were lower than the excretion of $\mathrm{P}$ in the category of growing piglets $\left(2600 \mathrm{mg} \cdot \mathrm{kg}^{-1}\right)$ [15]. The highest faecal excretion was recorded on the 7 th day of lactation for $\mathrm{Ca}, \mathrm{Mg}$; on the 14th day of lactation for P; and on the 28th day of lactation for $\mathrm{Na}$.
Our experimental observations of macro-mineral excretion in the lactating sows can be helpful not only from the view point of milk composition, but also from the environmental aspect, because some minerals (as for example phosphorus) in pig excrement can constitute risks for soil and water contamination.

\section{REFERENCES}

1. Abrams, S. A., Wong, W.W., 2003: Clinical protocols for absorption studies. In Stable Isotopes in Human Nutrition: Laboratory Methods and Research Applications, CABI Pub., 42-44.

2. Apple, J.K., Kegley, E.B., Maxwell, C.V., Rakes, L.K., Galloway, D., Wistuba, T. J., 2005: Effects of dietary magnesium and short-duration transportation on stress response, postmortem muscle metabolism, and meat quality of finishing swine. J. Anim. Sci., 83, 1633-1645.

3. Blaine, J., Chonchol, M., Levi, M., 2015: Renal control of calcium, phosphate, and magnesium homeostasis. Clin. J. Am. Soc. Nephrol., 10, 1257-1272.

4. Broekaert, J.A.C., 1998: Analytical Atomic Spectrometry with Flames and Plasmas, 3rd edn., Wiley-VCH, Weinheim, Germany, 158-159.

5. Close, W. H., Cole, D. J. A., 2000: Mineral requirements. In Nutrition of Sows and Boars. Nottingham University Press, 103-107.

6. Crenshaw, T. D., 2001: Calcium, phosphorus, vitamin D, and vitamin $\mathrm{K}$ in swine nutrition. In Lewis, A. J., Southern, L. L., (Eds.): Swine Nutrition. 2nd edn., CRC Press, Boca Raton, Florida, $187-212$.

7. Crocker, A. W., Robison, O. W., 2002: Genetic and nutritional effects on swine excreta. J. Anim. Sci., 80, 2809-2816.

8. Cromwell, G. L., 2015: Nutritional requirements of pigs. http://www.merckvetmanual.com/mvm/management_and_nutrition/nutrition_pigs/nutritional_requirements_of_pigs.html.

9. Daza, A., Bezerra Evangelista, J. N., Gutierrez Barquin, M. G., 1999: Milk production in crossbred sows (Large White $\times$ Landrace). Evolution and analysis of variation factors. Annales de Zootechnie, 48, 67-74.

10. D’souza, D. N., Warner, R.D., Leury, B. J., Dunshea, F. R., 1998: The effect of dietary magnesium aspartate supplementation on pork quality. J. Anim. Sci., 76, 104-109.

11. Ewing, W., Charlton, S. J., 2007: The Minerals Directory. 2nd edn., Context Products Ltd, Leicestershire, United Kingdom, Calcium 5a-19a. 
12. Farrel, E. C., 1984: Phosphorus. Clin Chem., 1072-1074

13. Fairweather-Tait, S., Hurrell, R. F., 1996: Bioavailability of minerals and trace elements. Nutr. Res. Reviews, 9, 295-324.

14. Giesemann, M.A., Lewis, A. J., Miller, P.S., Akhter, M.P., 1998: Effects of the reproductive cycle and age on calcium and phosphorus metabolism and bone integrity of sows. J. Anim. Sci., 76, 796-807.

15. Huaynate, R.A.R., Thomaz, M.C., Kronka, R.N., Fraga, A. L., Scandolera, A. J., Budiño, F. E. L., 2006: Effect of adding macro and micro minerals in pig feces fed diets with different levels of probiotic. Brazilian Archives of Biology and Technology, 49, 385-392.

16. Hurley, W. L., 2015: Composition of sow mammary secretions. In Farmer C. (Ed.): The Gestating and Lactation Sow, Chapter 9, Wageningen Press, 193-229.

17. Jolliff, J.S., 2011: Evaluating dietary macro- and micromineral sources, levels, and their environmental impact in the porcine species. In Mineral Metabolism. Dissertation thesis. The Ohio State University, 18-48.

18. Kornegay, E. T., Harper, A. F., 1997: Environmental nutrition: Nutrient management strategies to reduce nutrient excretion of swine. Proff. Anim. Sci., 13, 99-111.

19. Lantzsch, H. J., Wjst, S., Drochner, W., 1995: The effect of dietary calcium on the efficacy of microbial phytase in rations for growing pigs. J. Anim. Physiol. Anim. Nutr., 73, 19-26.

20. Lewis, A. J., Southern, L. L., 2001: Swine Nutrition. Sodium Metabolism, 2nd edn., CRC Press; Boca Raton, Florida, 222.

21. Mahan, D.C., Fetter, A.W., 1982: Dietary calcium and phosphorus levels for reproducing sows. J. Anim. Sci., 54, 285-291.

22. Mahan, D.C., 1990: Mineral nutrition of the sow. A review. J. Anim. Sci., 68, 573-582.

23. Mahan, D. C., 2006: The changing mineral status of high producing sows. In Proc. Swine Nutrition Conf., Indianapolis, 7th Sept., $17-27$.
24. Maxson, P. F., Mahan, D. C., 1986: Dietary calcium and phosphorus for lactating swine at high and average production levels. J. Anim. Sci., 63, 1163-1172.

25. Pohl, H. R., Wheeler, J.S., Murray, H.E., 2013: Sodium and Potassium in Health and Disease. In Sigel, A., Sigel, H., Sigel, Roland K. O.: Interrelations Between Essential Metal Ions and Human Diseases. Chapter 2: Metal ions in life sciences 13. Springer, 29-47.

26. Rebollar, P.G., Mateos, G.G., 2003: El fósforo en nutrición animal, necesidades, valoración de materias primas y mejora de la disponibilidad. In Curso de Especialización Avances en Nutrición y Alimentación Animal, 15., Madrid. Anales. Available in: www.etsia.upm.es/fedna/capitulos/99CAP2.pdf. Access on Jan. $15,2003$.

27. Richards, M.P., Close, W.H., 2001: Mineral nutrition of the sow. In Lyons, T. P., Cole, D. J. A. (Eds.): Concepts in Pig Science. Nottingham University Press, Nottingham, UK, 131-145.

28. Šimeček, K., Zeman, L., Heger, J., 1994: Requirement of nutrients and nutritious value of feed for pigs. In Brestenský et al.: Guide of Breeder. Research institute for animal production Nitra, SR, 112-113.

29. Tang, D. H., 2000: Effect of feeding magnesium sulfate to fattening pigs on constipation. Lives. Poult. Ind., 6, 24-25.

30. Underwood, E. J., Suttle, N. F., 1999. The Mineral Nutrition of Livestock. CABI Publishing, New York. 149-185.

31. Vrzgula, L., Sokol, J., 1990: Metabolic Profile Tests Values in Domestic Animals and their Interpretation. Macro and Micromineral Profile (In Slovak). Institute of Postgraduate Education of Veterinary Surgeons in Košice, SR, 10-19.

32. Žvorc, Z., Mrljak, M., Sušić, V., Gotal, J. P., 2006: Haematological and biochemical parameters during pregnancy and lactation in sows. Vet. Arh., 76, 245-253.

Received May 19, 2016 